Ciencias

$\frac{\text { Veterinarias }}{\text { ancorkents }}$
Rev. Ciencias Veterinarias, Vol. 37, N³, [13-17], E-ISSN: 2215-4507

First Symposium on Regenerative Medicine and Nanotechnology, Costa Rica 2019

URL: http://www.revistas.una.ac.cr/index.php/veterinaria/index

\title{
Tissue particularities and problems related to bone healing and fracture repair
}

\section{Particularidades del tejido y problemas relacionados con la cicatrización ósea y la reparación de fracturas}

\section{Christophorus Lischer ${ }^{1}$}

1 Equine Clinic, Surgery and Radiology, Free University of Berlin, Berlin, Germany. Email: christoph.lischer@fu-berlin.de

\begin{abstract}
The natural bone repair processes are sufficient to effect timely restoration of skeletal integrity for most fractures when an appropriate mechanical environment exists or is created with internal fixation or coaptation. However, some situations require manipulation or augmentation of natural healing mechanisms to regenerate larger quantities of new bone than would naturally occur to achieve surgical goals. Examples include substantial loss of host bone from trauma, arthrodesis, non- or delayed unions, or insufficient healing potential of the host because of local or systemic disease, e.g. bone infection or osteocyst like lesions.

Materials and strategies that are employed must duplicate and amplify the events of secondary bony formation to achieve the desired result.

Bone can be regenerated through the following strategies: osteogenesis-the transfer of cells; osteoinduction-the induction of cells to become bone; osteoconduction, providing a scaffold for bone forming cells; or osteopromotion - the promotion of bone healing and regeneration by encouraging the biologic or mechanical environment of the healing or regenerating tissues. The most efficacious strategies use as many of these fundamental components of bone regeneration as possible (Figure 1).
\end{abstract}

Table 1: Definition of functions of bone grafts and synthetic bone replacements.

\begin{tabular}{|l|l|}
\hline Osteogenic graft & A graft that supplies and supports bone forming cells \\
\hline Osteoinductive graft & $\begin{array}{l}\text { A material that has the capacity to induce bone formation when placed into a site where } \\
\text { no bone formation will occur }\end{array}$ \\
\hline Osteoconductive graft & $\begin{array}{l}\text { A material that provides a scaffold for mesenchymal cells, osteoclasts and osteoblasts to } \\
\text { migrate into and proliferate within }\end{array}$ \\
\hline Osteopromotive graft & A material or physical impetus that results in enhancement of regenerating bone \\
\hline Supportive graft & A material that provides additional support to the bone \\
\hline
\end{tabular}


Ciencias

Veterinarias

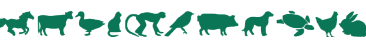

Rev. Ciencias Veterinarias, Vol. 37, N³, [13-17], E-ISSN: 2215-4507

First Symposium on Regenerative Medicine and Nanotechnology, Costa Rica 2019 DOI: https://doi.org/10.15359/rcv.37-3.4

URL: http://www.revistas.una.ac.cr/index.php/veterinaria/index

\section{Bone grafts}

\section{Type:}

The gold standard for augmenting bone healing in humans and other animals remains autogenous cancellous bone graft. More than 500,000 bone grafting procedures are performed annually in human patients in the United States, and 2.2 million are completed worldwide. The number performed in companion animals, while undocumented, is also likely to be substantial.

\section{Classification:}

Bone grafts are typically classified according to the origin (i.e., autograft, allograft or xenograft), tissue type (i.e. cancellous, cortical, corticocancellous, osteochondral or vascularized), or locality of the graft (i.e. orthotopic [bone location] or heterotopic [non-bone location).

\section{Use:}

The cancellous bone is most commonly used in horses. It is very osteogenic and also has a potent osteoinductive capacity. Only 10 to $30 \%$ of the cells survive and only those on the surface of the graft. In horses, the cancellous bone can be harvested from the tuber coxae, sternum, and proximal tibia. Cortical bone graft is used uncommonly in horses or as part of a cortico-cancellous graft where it can contribute to the volume.

The vascular response to a cancellous autograft is rapid, and the entire cancellous bed may be completely revascularized within 1 - 2 weeks. The cell population of this environment is predominantly osteoblasts, likely derived from the recipient and descendants of cells transplanted with the graft itself. Osteoblasts line the trabeculae of the graft and deposit a seam of osteoid that surrounds and entraps the grafted dead bone that is eventually resorbed by osteoclasts. Cortical grafts are revascularized less quickly than cancellous grafts because the dense cortical bone does not allow a large contact area for vascular penetration between the graft and the host. Instead, revascularization occurs via the old haversian and Volkmann canals, and then follows the process of creeping substitution, wherein the cortical bone graft is first resorbed before it is replaced with new viable bone.

\section{Drawbacks of bone graft:}

Unfortunately, bone grafts have drawbacks. The additional anesthetic time or personnel needed for graft harvesting and the potential for an insufficient quantity of graft, limited access to donor sites, loss of osteogenic cells, donor site infection, pain or hemorrhage, and failure of the donor bone are factors complicating cancellous autograft procedures. Similarly, allografts and xenografts - though less commonly performed in horses - carry the hazards of immune-mediated rejection and graft sequestration and, although unreported, the potential risk of disease transmission between donor and host. Bone banks are also costly to maintain. 
Ciencias

Veterinarias

art?
Rev. Ciencias Veterinarias, Vol. 37, Nº 3, [13-17], E-ISSN: 2215-4507 First Symposium on Regenerative Medicine and Nanotechnology, Costa Rica 2019 DOI: https://doi.org/10.15359/rcv.37-3.4

URL: http://www.revistas.una.ac.cr/index.php/veterinaria/index

\section{Bone graft substitutes}

Accordingly, bone-graft substitutes have been developed as alternatives to autologous or allogeneic bone grafts. In their simplest form, they consist of scaffolds made of synthetic or natural biomaterials that promote the migration, proliferation, and differentiation of bone cells for bone regeneration. They are generally more effective, however, when used as delivery vehicles for one or more Bone Growth and Differentiation Factors (BGDFs). They can be categorized into organic and inorganic matrices.

\section{Organic matrices}

Organic matrices are comprised of two groups: Biological matrices such as demineralized bone matrix (DBM), non-collagenous proteins, collagen, fibrin and autolyzed antigen extracted allogeneic bone (AAA- bone) and synthetic matrices like polylactic acid or polyglycolic acid homoor heteropolymers. Collagen and synthetic polymer delivery vehicles offer the greatest potential for clinical use at this time.

Other organic delivery vehicles include hydrogels, autolyzed antigen-extracted allogeneic bone, inactivated dentin matrix, lyophilized cartilage and fibrin. They all suffer from poor load-bearing capacity and/or propensity for prompting foreign body responses.

Table 2: Function of bone grafts and synthetic bone replacements

\begin{tabular}{|l|c|c|c|c|}
\hline & Osteogenic & Osteo-conductive & Osteo-inductive & $\begin{array}{c}\text { Mechanical } \\
\text { support }\end{array}$ \\
\hline Autograft & & & & \\
\hline Cancellous bone & +++ & +++ & ++ & - \\
\hline Allograft & & & & \\
\hline Demineralized bone matrix & & + & +-++ & \\
\hline Synthetic bone replacement & & & & \\
\hline Calcium sulphate & & $(+)$ & & + \\
\hline Tricalcium phosphate & & ++ & & +-++ \\
\hline Hydroxyapatite & & ++ & & ++-++++ \\
\hline Bone morphogenic proteins & & & ++++ & \\
\hline
\end{tabular}

Allographs, such as demineralised bone matrix, are possible in horses. However, they require special preparation (demineralisation) and storage. This is not practical in many equine orthopaedic situations, such as fractures where prompt treatment is crucial. Furthermore, the allogenic bone demonstrates a lower osteogenic capacity (lower rate of new bone formation), a higher resorption rate, a greater immunogenic response, and less revascularisation of the graft than the autogenous cancellous bone. In a rib-defect model in horses there was no evidence of enhanced healing associated with the use 
Ciencias

Veterinarias
Rev. Ciencias Veterinarias, Vol. 37, Nº 3, [13-17], E-ISSN: 2215-4507

First Symposium on Regenerative Medicine and Nanotechnology, Costa Rica 2019 DOI: https://doi.org/10.15359/rcv.37-3.4

URL: http://www.revistas.una.ac.cr/index.php/veterinaria/index

of equine demineralized bone matrix (Kawcak et al. 2000). These are some of the reasons why the allogenic bone has never become very popular in equine surgery.

Limited availability and concerns relating to complications such as possible transmission of virus to the recipient have prompted search for bone-graft substitutes, such as ceramics (Calcium sulphate, Tricalcium phosphate, Hydroxyapatite) or single purified molecules for stimulating bone healing (bone morphogenic proteins, parathyroid hormone) or a combination of both. In equine surgery there is always the question of whether the cost of artificial bone replacements can be justified, because there is not enough clinical evidence for their efficiency. However a recent study revealed encouraging results in this regard (Perrier et al. 2008).

So far, Gene-Therapy and Stem-Cell have not had a breakthrough, but Bone-Tissue engineering seems to be the rising star in this concert.

Bone-tissue engineering combines progenitor cells, such as MSCs (native or expanded) or mature cells (for osteogenesis) seeded in biocompatible scaffolds and ideally in three-dimensional tissuelike structures (for osteoconduction and vascular ingrowth), with appropriate growth factors (for osteoinduction), in order to generate and maintain bone. The need for such improved composite grafts is obvious, especially for the management of large bone defects, for which the requirements for grafting material are substantial. At present, composite grafts that are available include bone synthetic or bioabsorbable scaffolds seeded with bone-marrow aspirate or growth factors (BMPs). Recently, an animal study has shown the potential for prefabrication of vascularized bioartificial bone grafts in vivo using b-TCP scaffolds intraoperatively filled with autogenous bone marrow for cell loading, and implanted into the latissimus dorsi muscle for potential application at a later stage for segmental bone reconstruction, introducing the principles of bone transplantation with minimal donor-site morbidity and no quantity restrictions. Another current approach to enhance bone regeneration and soft-tissue healing simultaneously is by local application of growth factors in the form of platelet-rich plasma (PRP), a volume of the plasma fraction of autologous blood with platelet concentrations above baseline, which is rich in many of the aforementioned molecules. A carrier matrix can be used (e.g. ACS). The PRP composite can then be wrapped around implants or the fracture itself or can be laid directly on the tissue bed of open wounds.

\section{References}

Damien, C.J. \& Parsons, J.R. 1991. Bone graft and gone graft substitutes: A review of current technologies and applications. J. Appl. Biomater. 2(3): 187-208

Janicek, J.C., Cook, J.L., Wilson, D.A. \& Ketzner, K.M. 2010. Multiple osteochondral autografts for treatment of a medial trochlear ridge subchondral cystic lesion in the equine tarsus. Vet. Surg. 39(1): 95-100. DOI: 10.1111/j.1532-950X.2009.00576.x 
Ciencias

Veterinarias

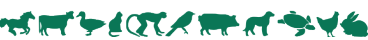

Rev. Ciencias Veterinarias, Vol. 37, N³, [13-17], E-ISSN: 2215-4507

First Symposium on Regenerative Medicine and Nanotechnology, Costa Rica 2019 DOI: https://doi.org/10.15359/rcv.37-3.4

URL: http://www.revistas.una.ac.cr/index.php/veterinaria/index

Kawcak, C.E., Trotter, G.W., Powers, B.E., Park, R.D. \& Turner, A.S. 2000. Comparison of bone healing by demineralized bone matrix and autogenous cancellous bone in horses. Vet. Surg. 29(3): 218226. DOI: $10.1053 /$ jvet.2000.5601

Perrier, M., Lu, Y., Nemke, B., Kobayashi, H., Peterson, A. \& Markel, M. 2008. Acceleration of second and fourth metatarsal fracture healing with recombinant human bone morphogenetic protein-2/calcium phosphate cement in horses. Vet. Surg. 37(7): 648-655. DOI: 10.1111/j.1532950X.2008.00431.x 